lated institutions of higher learning, the university, the agricultural college, the normal school and the school of mines at some city which is desirably situated. The plan is supported by the proposed conversion of the plans and equipment that would otherwise be abandoned into a system of polytechnic high schools.

A comprehensive outline of the change sought to be effected is given in the constitution and by-laws of the association, organized at that time before the meeting of the board. This follows:

The name of the organization shall be "The Association for the Creation of a Greater University of Montana."

The purpose of this association shall be:

1. To consolidate the four higher educational institutions of the state in order to prevent the educational and financial waste brought about by the maintenance of separate and isolated institutions.

2. To establish, instead of the four institutions, a greater University of Montana to be situated in or near some city suitable by reason of its railroad connections, climate and water and health conditions to be a great seat of learning.

3. To work for the creation of a splendid system of polytechnic high sehools which are at the present time so much needed; this to be brought about by means of $(a)$ the utilization of all the present plants that would otherwise be abandoned, (b) the utilization of the military post .at Fort Assiniboine if the government turns it over to the state; (c) the establishment of similar schools in other sections of the state as they may from time to time be needed.

4. To impress on the attention of philanthropic persons, especially men of great means, the desirability of aiding the development of the University of Montana, through the provision of buildings and endowments.

5. To arouse public sentiment in favor of education and to arouse the enthusiasm of the people to the unsurpassed educational possibilities of the great commonwealth of Montana.

The state board of education, after giving a hearing to the representatives of this resolution, unanimously adopted resolutions recommending that the legislature consolidate the institutions and pledging the members to do all within their power to encompass the result sought.

\section{THOMAS HARRISON MONTGOMERY}

AT the recent meeting of the American Society of Zoologists in Cleveland, Ohio, the following resolution was submitted by Dr. A. G. Mayer on behalf of the executive committee. The resolution was then approved by a rising vote of the society.

Never has a deeper sense of irreconcilable sorrow fallen upon us of this society than that following the announcement of the death of Thomas Harrison Montgomery on the nineteenth day of March, 1912, at the early age of thirty-nine years.

Other friends, leaders in science, have gone before, but they were full of years and the labor of their lives was as a story well nigh told; but with Montgomery the tasks that lay before him were those of the greater years of life, that period of intellectual fruition for the harvest of which his years of toil and training had been a preparation.

While thus but upon the threshold of his middle years, science lost him; but irreparable as these things be, it is as our friend we mourn him most.

No ordinary motives actuated him in his scientific work, for personal ambition never clouded his simple love for truth wherever truth might lead him.

It is to unselfish men such as he that great opportunities are entrusted, and the equipment and organization of the new Zoological Laboratory of the University of Pennsylvania was a task he had all but completed, and this will serve as a fitting monument to his ability as an executive.

On the scientific side, he was the author of nearly one hundred publications, and it would be impossible to write a text-book upon the rôle of the chromosomes in the determination of sex without referring to his crucial labors in this field.

It is seldom that we see a man even far advanced in years attain to the achievement he accomplished. Yet as our friend and our companion we mourn him most, for seience will and must be advaneed; but to us there ever will be but one Montgomery, the generous friend, sympathetic and simple, Montgomery the gentleman who loved us and whom we loved.

W. C. Curtis, Secretary 